\title{
Diagnoza w postępowaniu karnym wobec nieletnich przestępców we Francji
}

\author{
Paulina Perska-Gradowska \\ ORCID: 0000-0001-7060-2910 \\ Zakład Penitencjarystyki \\ Uniwersytet im. Adama Mickiewicza w Poznaniu
}

\section{Zdolność do rozeznania czynu jako warunek odpowiedzialności karnej}

W literaturze przedmiotu wyróżnia się wiele modeli postępowania $\mathrm{z}$ nieletnimi ${ }^{1}$. W niektórych nieletni przedstawiani są jako osoby racjonalne, które są zdolne do ponoszenia odpowiedzialności za popełnione czyny. W postępowaniu dominujące znaczenie ma czyn, którego dopuścił się nieletni, rodzaj i waga tego czynu. Ze względu na przypisanie racjonalności modele te często przyjmują kryterium rozeznania oraz dolną granicę wiekową odpowiedzialności karnej. Wobec nieletnich stosuje się postępowanie formalne z zapewnieniem gwarancji i praw procesowych. Przewidują one także stosowanie kar zawartych w ustawach karnych.

Można także wyróżnić modele, które traktują nieletnich przestępców jako ofiary wadliwej socjalizacji i niekorzystnych warunków środowiskowych. Zgodnie z tym założeniem nieletni nie odpowiada karnie za popełniony czyn. W modelach tych postępowanie ma charakter niefor-

${ }^{1}$ Zob. np. B. Stańdo-Kawecka, Prawo karne nieletnich. Od opieki do odpowiedzialności, Warszawa 2007, s. 25-29; A. Walczak-Żochowska, Modele postępowania z nieletnimi, [w:] Problemy prawa polskiego i obcego w ujęciu historycznym, praktycznym i teoretycznym, cz. 4, red. B. Bieńkowska, D. Szafrański, Warszawa 2013, s. 252-253; M. Cavadino, J. Dignan, Penal Systems: A Comparative Approach, London 2005, s. 199-211.

Nowa Kodyfikacja Prawa Karnego 53, 2019

(C) for this edition by CNS 
malny, a ustawodawca rezygnuje z przyznania osobom nieletnim gwarancji i praw procesowych. Celem postępowania i orzekanych środków nie jest ukaranie nieletniego, lecz jego wychowanie oraz zapewnienie mu właściwej opieki i ochrony.

Francuski model przyjmuje, że nieletni ponosi odpowiedzialność karną za popełnione przestępstwa. Odpowiedzialność karna nieletnich opiera się na zasadach ogólnych zawartych we francuskim kodeksie karnym oraz na rozporządzeniu z 2 lutego 1945 roku dotyczącym nieletnich przestępców $^{2}$. Rozporządzenie to zawiera przepisy szczególne odnoszące się do sądownictwa dla nieletnich oraz środków wychowawczych, sankcji wychowawczych i kar, jakie mogą być stosowanie wobec osób nieletnich.

Francuskie prawo i doktryna przyjęły trójelementową konstrukcję przestępstwa. Składa się ono z elementu legalnego, materialnego i moralnego.

Pierwszy z nich — element legalny — istnieje, gdy określone działanie bądź zaniechanie zostało zabronione przez ustawę. Wyraża on zasadę nullum crimen sine lege. Zasada ta wynika $\mathrm{z}$ art. $111^{2} \mathrm{i} 111^{3}$ francuskiego kodeksu karnego ${ }^{3}$.

Francuskie prawo karne posługuje się pojęciem elementu materialnego w stosunku do zachowania. Może ono polegać na działaniu zabronionym przez prawo lub zaniechaniu zachowania nakazanego. Jest to więc materializacja woli zachowania niezgodnego z prawem.

Ostatni z elementów określających przestępstwo - element moralny — odnosi się do świadomości lub woli popełnienia czynu zabronionego.

W orzeczeniu z 13 grudnia 1956 roku Sąd Kasacyjny (Cour de cassation) podkreślił, że każde przestępstwo, nawet nieumyślne, zakłada, że osoba, która je popełniła, działała w sposób rozumny i z wolą (,,toute infraction même non intentionnelle, suppose que son auteur ait agi avec intelligence et volonté") ${ }^{4}$. Element ten jest związany z problemem winy.

2 Ordonnance ${ }^{\circ}$ 45-174 du 2 février 1945 relative à l'enfance délinquante, Journal Officiel du 4 février 1945.

3 Art. $111^{2}$ Kodeksu karnego stanowi, że ustawa wskazuje zbrodnie i występki, natomiast rozporządzenie - wykroczenia. W myśl art. $111^{3}$ k.k. nikt nie może zostać ukarany za zbrodnię lub występek, którego elementy nie zostały określone przez ustawę, ani za występek, którego elementów nie opisano w rozporządzeniu.

${ }^{4}$ Cour de cassation, Chambre criminelle, du 13 décembre 1956, 55-05.772, https:// www.legifrance.gouv.fr/affichJuriJudi.do?idTexte=JURITEXT000007054042 (dostęp: 25.06.2018). 
We Francji wyznaczono kilka granic wiekowych odpowiedzialności karnej nieletnich. Granice te mają zastosowanie przede wszystkim w możliwości wykorzystania określonych środków, sankcji czy kar. $\mathrm{Z}$ punktu widzenia odpowiedzialności karnej najważniejsze znaczenie ma pierwsza z nich, którą stanowi wiek 6-8 lat. Poniżej tej granicy uznaje się, że dziecko nie jest zdolne do rozeznania czynu, a zatem nie ponosi odpowiedzialności karnej. Warto podkreślić, że granica ta została ustanowiona przez orzecznictwo ${ }^{5}$, natomiast akty prawne nie regulują dolnej granicy wiekowej odpowiedzialności karnej nieletnich. Wprowadzenie różnych granic wiekowych dla możliwych reakcji na popełnienie przestępstwa nie rozwiązuje jednak problemu niewyznaczenia dolnej granicy wiekowej odpowiedzialności karnej. Można zatem stwierdzić, że granice odpowiedzialności karnej nieletnich obejmują wiek, od którego dziecko jest zdolne do rozeznania znaczenia czynu, do ukończenia 18. roku życia.

Artykuł $122^{8}$ francuskiego kodeksu karnego stanowi, że nieletni, którzy są zdolni do rozpoznania swoich czynów, ponoszą odpowiedzialność karną za zbrodnie, występki i wykroczenia, jeżeli zostali uznani za winnych, na podstawie ustawy szczególnej określającej środki ochrony, asysty, nadzoru i wychowawcze:

Les mineurs capables de discernement sont pénalement responsables des crimes, délits ou contraventions dont ils ont été reconnus coupables, dans des conditions fixées par une loi particulière qui détermine les mesures de protection, d'assistance, de surveillance et d'éducation dont ils peuvent faire l'objet ${ }^{6}$.

Ustawą szczególną jest wspomniane rozporządzenie z 1945 roku.

Kryterium rozeznania decyduje o odpowiedzialności karnej. F. Dekeuwer-Défossez definiuje odpowiedzialność karną jako zdolność ponoszenia odpowiedzialności za swoje czyny, co oznacza chęć i wolny wybór w zakresie ich popełnienia. Dalej postuluje, że dzieci, które nie mają rozeznania, nie powinny odpowiadać za czyny ze względu na niemożliwość przewidywania ich znaczenia i konsekwencji ${ }^{7}$. Podobnie stwierdza Ch. Courtin, nawiązując do orzeczenia Sądu Kasacyjnego z dnia 13

\section{Ibidem.}

${ }^{6}$ Loi n ${ }^{\circ}$ 92-683 du 22 juillet 1992, Code pénal, Journal officiel de la République Française $n^{\circ} 169$ du 23 juillet 1992, art. $122^{8}$.

${ }^{7}$ F. Dekeuwer-Défossez, L'instrumentalisation du discernement de l'enfant, „Recherches familiales" 2012, nr 1, s. 164. 
grudnia 1956 roku, że nieletniemu można zarzucić popełnienie jakiegokolwiek przestępstwa, jeżeli sędzia uzna, że działał on ze świadomością oraz wolną wolą 8 .

Należy zwrócić uwagę, że francuskie ustawodawstwo nie przyjmuje kryterium wieku w odniesieniu do kwestii ponoszenia odpowiedzialności karnej przez dzieci i młodzież. Jest to związane z przyjęciem kryterium rozeznania. Jak podkreślił Sąd Kasacyjny w wyroku w sprawie J. Laboube z 13 grudnia 1956 roku, brak odpowiedzialności karnej dotyczy wyłącznie nieletnich, którzy nie potrafią rozeznać popełnionego czynu 9 . Wobec tego każdy nieletni zdolny do rozeznania popełnioneg czynu ponosi odpowiedzialność karną bez względu na wiek. Nieletni nie ponosi natomiast odpowiedzialności karnej, jeżeli w chwili popełnienia czynu nie był zdolny do rozeznania.

Podsumowując, należy stwierdzić, że warunkiem odpowiedzialności karnej nieletniego jest jego działanie z rozeznaniem i możliwość przypisania winy. Zgodnie z uzasadnieniem projektu francuskiego kodeksu karnego trzeba przyjąć, że wina nieletniego traktowana jest jako wina ograniczona. Takie założenie jest związane z wiekiem nieletniego i jego niedojrzałością ${ }^{10}$.

Wobec opisanych uregulowań problemu odpowiedzialności karnej nieletnich niezbędna staje się diagnoza wykonywana na zlecenie sądu.

\section{Diagnoza nieletniego, jego rodziny i środowiska funkcjonowania}

Diagnoza wykonywana na zlecenie sędziego dla nieletnich służy przede wszystkim ustaleniu stopnia rozwoju sprawcy. Nieletni odpowiada karnie, tylko jeżeli jego stopień rozwoju pozwala domniemywać, że rozumie on znaczenie popełnionego czynu i jest świadomy jego bezprawności. Zdolność do rozeznania czynu jest bowiem niezbędna do

${ }^{8}$ Ch. Courtin, France. La responsabilite penale des mineurs dans l'ordre interne et international, „Revue internationale de droit pénal” 2004, nr 1, s. 340.

${ }^{9}$ Cour de cassation, Chambre criminelle, du 13 décembre 1956.

10 B. Stańdo-Kawecka, Odpowiedzialność karna nieletnich a nowy kodeks karny, „Palestra” 1998, nr 42, s. 18. 
przypisania winy. Badając stopień rozwoju nieletniego, należy uwzględnić rozwój zarówno biologiczny, jak i psychologiczny (intelektualny, moralny, emocjonalny).

W art. 8 rozporządzenia z 2 lutego 1945 roku ustanowiono, że sędzia dla nieletnich jest odpowiedzialny za podjęcie działań mających na celu zbadanie osobowości nieletniego, a w konsekwencji orzeczenie odpowiednich środków z punktu widzenia jego reedukacji. Jest on także organem uprawnionym do zlecania badań medycznych oraz medyczno-psychologicznych; oprócz tego sędzia dla nieletnich zbiera wszelkie informacje dotyczące środowiska rodzinnego i społecznego, w którym nieletni funkcjonuje. Wśród podstawowych informacji pozyskiwane są więc te dotyczące osobowości osoby nieletniej, sytuacji materialnej rodziny, warunków, w jakich wychowywana jest osoba nieletnia, wartości rodzinnych, stosunku nieletniego do obowiązku szkolnego, sytuacji zdrowotnej oraz rozwoju psychicznego. W tym celu sędzia dla nieletnich może stosować środki, których celem jest poznanie sytuacji nieletniego. Jednym z nich jest MJIE (mesure judiciaire d'investigation éducative sądowy środek wywiadu wychowawczego).

MJIE powstał na mocy rozporządzenia $\mathrm{z}$ dnia 2 lutego 2011 roku $^{11}$. Jest to środek stosowany $\mathrm{w}$ ramach systemu sądowej ochrony dzieci i młodzieży, służący do oceny osobowości nieletniego, jego sytuacji rodzinnej i społecznej. MJIE może być wykonywany przez podmioty publiczne albo instytucje zarządzane przez stowarzyszenia, które otrzymały państwowe upoważnienie do wykonywania orzeczeń w sprawach cywilnych i karnych. Warto podkreślić, że omawiany środek może być orzeczony w wypadku postępowania zarówno karnego, jak i cywilnego ${ }^{12}$. Niezależnie jednak od podstawy cywilnej lub karnej wszelkie działania prowadzone na podstawie MJIE muszą uwzględniać zasadę działania zgodnie z interesem dziecka; nie mogą ponadto wykraczać poza ramy ustanowione w orzeczeniu sądowym.

11 Arrêté du 2 février 2011 portant création de la mesure judiciaire d'investigation éducative, JORF $n^{\circ} 0047$ du 25 février 2011 page 3409, texte $n^{\circ} 10$.

12 Środek MJIE stosowany jest w postępowaniu karnym w wypadku popełnienia przez nieletniego przestępstwa, natomiast w postępowaniu cywilnym wykorzystywany jest, kiedy rodzice nie realizują wobec dziecka obowiązków wynikających z władzy rodzicielskiej i konieczne jest orzeczenie środka w postaci asysty wychowawczej. 
Zgodnie z obwieszczeniem z dnia 23 marca 2015 roku dotyczącym stosowania MJIE ${ }^{13} \mathrm{w}$ sprawach karnych zbierane są informacje na temat: sytuacji materialnej rodziny, osobowości dziecka, jego obecności w szkole, jego predyspozycji i postawy wobec szkoły, warunków, w jakich funkcjonuje, jego zdrowia i rozwoju psychologicznego, a także środków właściwych do jego wychowania. Ponadto uwzględniane są informacje dotyczące wcześniejszych postępowań oraz orzeczonych środków o charakterze sądowym lub administracyjnym. Wszelkie zebrane informacje stanowią podstawę dla sędziego lub sądu dla nieletnich do orzeczenia odpowiedniego środka, sankcji lub kary zmierzających do wychowania nieletniego i reintegracji społecznej.

MJIE charakteryzuje się przede wszystkim interdyscyplinarnością. Wynika to z konieczności zebrania danych dotyczących nie tylko nieletniego, ale też jego rodziny i środowiska funkcjonowania. Interdyscyplinarność wpływa również na skład zespołu dokonującego diagnozy w sprawach karnych, który może się składać z wychowawcy, psychologa, asystenta socjalnego, lekarza psychiatry i/lub pediatry. Warto zaznaczyć, że w uzasadnionych przypadkach do zespołu diagnozującego można włączyć także innych specjalistów, na przykład osoby zajmujące się działaniami prewencyjnymi, personel ośrodków zdrowotnych czy doradców zawodowych ${ }^{14}$. Holistyczny opis sytuacji nieletniego niewątpliwie zwiększa prawdopodobieństwo orzeczenia najbardziej odpowiedniego środka czy kary.

Do 2015 roku MJIE mógł być realizowany w dwojaki sposób ${ }^{15}$. Po pierwsze, sędzia dla nieletnich mógł nakazać wykonanie środka w podstawowym zakresie, a w trakcie postępowania z inicjatywy lub na wniosek stron mógł zarządzić pogłębienie wywiadu w określonej dziedzinie. Po drugie, sędzia mógł zarządzić wykonanie MJIE, wskazując na początku, które z elementów diagnozy należy pogłębić. O sposobie reali-

13 Note du 23 mars 2015 relative à la mesure judiciaire d'investigation éducative, Bulletin Officiel Du Ministère De La Justice Et Des Libertés, NOR : JUSF1507871N.

14 Ibidem.

15 Obwieszczenie z dnia 23 marca 2015 roku uchyliło okólnik dotyczący MJIE (Circulaire d'orientation du 31 décembre 2010 relative à la mesure judiciaire d'investigation éducative, Bulletin Officiel Du Ministère De La Justice Et Des Libertés, NOR : JUSF1034029C). 
zacji środka decydował zatem sędzia, a zakres, w jakim realizowany był MJIE, był dostosowany do sytuacji nieletniego — środek ten charakteryzował się więc pewną elastycznością. Obecne uregulowania nie przyznają jednak sędziom uprawnień do decydowania o zakresie zbieranych informacji. Oznacza to, że środek ten jest wykonywany w jednolitym zakresie uregulowanym w obwieszczeniu z 2015 roku.

Aktualnie elementy, które są diagnozowane, koncentrują się wokół osobowości nieletniego, środków odpowiednich ze względu na reedukację, sytuacji rodzinnej, warunków wychowawczych i relacji rodzinnych, kontekstu popełnienia przestępstwa z uwzględnieniem środowiska społeczno-wychowawczego oraz biografii nieletniego, wcześniejszych kontaktów z wymiarem sprawiedliwości, postawy w stosunku do szkoły i realizacji obowiązku szkolnego, a także stanu zdrowia.

Do 2015 roku obowiązywały również szczególne kryteria sporządzania diagnozy w każdym z obszarów ${ }^{16}$. W sprawach karnych w sferze dotyczącej osobowości nieletniego należało zbadać wszystkie elementy, które mogły mieć wpływ na osobowość. Wśród przykładowych należy wymienić: postawy rodziców wobec prawa i ich stosunek do norm społecznych, symptomy świadczące o izolacji dziecka od środowiska zewnętrznego oraz o integracji społecznej, poziom identyfikacji nieletniego z normami społecznymi, poziom samooceny oraz postrzeganie swojej roli w społeczeństwie. Diagnoza osobowości nie powinna być jednak ograniczona wyłącznie do badania cech psychologicznych. Według okólnika z 2010 roku konieczne jest także ustalenie, jakie elementy mogą wpływać na osobowość nieletniego.

W drugim z obszarów - sytuacji rodzinnej — wskazywano na konieczność zbadania takich elementów, jak: styl życia rodziny, warunki materialne, typ rodziny i relacje pomiędzy członkami, rodzaje otrzymywanej pomocy czy zasoby, jakimi dysponuje rodzina. Ponadto zalecano uzupełnić informacje danymi dotyczącymi otoczenia, w którym funkcjonuje rodzina. Uwzględnienie informacji takich, jak: miejsce zamieszkania, gęstość zaludnienia, poziom przestępczości i bezpieczeństwa, w diagnozie stawianej na potrzeby postępowania karnego wydaje się uzasadnione z punktu widzenia wyboru odpowiedniego środka wychowawczego.

16 Circulaire d'orientation du 31 décembre 2010. 
Kolejny obszar diagnozowania ujęty w okólniku z 2010 roku dotyczył kontekstu popełnienia przestępstwa z uwzględnieniem środowiska funkcjonowania. W sprawach karnych ten obszar ma szczególne znaczenie, ponieważ pozwala ustalić znaczenie przekroczenia norm prawnych, również z punktu widzenia nieletniego. Pozwala też ocenić, czy nieletni rozumiał konsekwencje czynu także w odniesieniu do potencjalnej ofiary. Tę sferę należy połączyć z następną — dotyczącą wcześniejszych kontaktów nieletniego z wymiarem sprawiedliwości. Analiza informacji na temat ewentualnych wcześniejszych postępowań w sprawie nieletniego pozwala ustalić, czy popełniony czyn ma charakter epizodyczny, jednostkowy, czy stanowi kolejne wykroczenie przeciw normom.

Następny obszar dotyczył sytuacji szkolnej nieletniego. Okólnik zalecał uwzględnianie informacji na temat frekwencji szkolnej, postawy wobec obowiązku szkolnego, zachowania podczas lekcji, słabych i mocnych stron nieletniego oraz zainteresowań. Co więcej, należało zdiagnozować potencjalne przyczyny niepowodzeń szkolnych, na przykład brak zainteresowania ze strony rodziców, niedostateczna integracja z rówieśnikami, nieuczestniczenie w grupach zainteresowań ${ }^{17}$.

Obecnie, na mocy obwieszczenia z 2015 roku, nie istnieją wytyczne ogólnokrajowe dotyczące elementów diagnozowania w każdym ze wskazanych obszarów. Zgodnie z tym dokumentem każdy zakład czy instytucja wykonująca MJIE jest zobowiązana do ustalenia elementów i narzędzi niezbędnych do sporządzenia diagnozy.

MJIE w sprawach karnych, zgodnie z obwieszczeniem z dnia 23 marca 2015 roku, musi być zrealizowany w ciągu sześciu miesięcy od powiadomienia odpowiedniej służby czy instytucji ${ }^{18}$. Skutkiem wykonania MJIE jest raport uwzględniający sytuację nieletniego oraz propozycje odnośnie do orzeczenia określonych środków jako najbardziej odpowiednich z punktu widzenia reedukacji nieletniego przestępcy. Warto zaznaczyć, że sędzia nie jest związany propozycją orzeczenia danego środka, jednakże stanowi ona pomoc w podjęciu decyzji ${ }^{19}$.

Poza MJIE warto także wspomnieć o innych środkach diagnostycznych. Jednym z nich jest obserwacja nieletniego w odpowiedniej placów-

17 Ibidem.

18 Note du 23 mars $2015 \ldots$

19 V. Freund, Le métier d'éducateur de la PJJ, Paris 2010, s. 92. 
ce. Sędzia dla nieletnich może orzec tymczasowe umieszczenie nieletniego w placówce, jeżeli niezbędna jest jego obserwacja ze względu na stan zdrowia fizycznego lub psychicznego ${ }^{20}$. Innym środkiem jest RRSE (le recueil de renseignements socio-éducatifs — zbieranie informacji o charakterze społeczno-wychowawczym). Jest on wykonywany przez służby należące do systemu sądowej ochrony młodzieży (les services de la protection judiciaire de le jeunesse). Środek RRSE polega na zbieraniu informacji o charakterze społeczno-wychowawczym ${ }^{21}$. Jest to forma wywiadu, w którym uwzględnia się informacje dotyczące sytuacji rodzinnej, wykonywania władzy rodzicielskiej, sytuacji społecznej, środowiska funkcjonowania nieletniego, jego zdrowia i sytuacji szkolnej. Zwraca się także uwagę na rodzaj popełnionego przestępstwa oraz wcześniejsze postępowania sądowe lub administracyjne ${ }^{22}$. W przeciwieństwie do MJE nie jest to środek o charakterze interdyscyplinarnym i ogranicza się do ustalenia podstawowych faktów na temat sytuacji nieletniego. Podobnie jednak jak w wypadku MJIE środek ten zawiera propozycje o charakterze wychowawczym skierowane do sędziego lub sądu dla nieletnich.

\section{Podsumowanie}

Niewątpliwie postępowanie diagnostyczne ma istotne znaczenie w systemie przyjmującym odpowiedzialność karną nieletnich ze względu na możliwość rozeznania popełnionego czynu. Diagnoza w systemie francuskim pełni podwójną funkcję. Po pierwsze, pozwala odpowiedzieć na pytanie, czy nieletni w czasie popełnienia przestępstwa działał z rozeznaniem, a w konsekwencji, czy może ponieść odpowiedzialność karną. Nieustalenie dolnej granicy wiekowej odpowiedzialności karnej powoduje jednak, że w każdym przypadku niezbędne jest badanie, czy nieletni jest w ogóle zdolny do rozeznania czynu. Po drugie, stanowi ona pomoc dla sędziego czy sądu dla nieletnich w wyborze odpowiedniego środka,

${ }^{20}$ Ordonnance $n^{\circ}$ 45-174 du 2 février 1945 relative à l'enfance délinquante, Journal Officiel du 4 février 1945, art. 10.

21 Ordonnance $\mathrm{n}^{\circ} 45-174$ du 2 février 1945, art. 8, art. $8^{1}$, art. 12.

22 Note d'instruction du 7 janvier 2014 relative à la mise en œuvre de l'article 12-3 de l'ordonnance du 2 février 1945 relative à l'enfance délinquante, Bulletin Officiel Du Ministère De La Justice, NOR : JUSF1401444N. 
sankcji lub kary. Interdyscyplinarne podejście i wieloaspektowe badanie sytuacji nieletniego i jego rodziny umożliwia także ustalenie motywów postępowania. Diagnoza ma ważne znaczenie również z punktu widzenia realizacji celu postępowania karnego w sprawach nieletnich przestępców, jakim jest wychowanie i wdrożenie do funkcjonowania w społeczeństwie zgodnie z normami społecznymi i prawnymi.

\section{Bibliografia}

Arrêté du 2 février 2011 portant création de la mesure judiciaire d'investigation éducative, JORF ${ }^{\circ} 0047$ du 25 février 2011 page 3409, texte $n^{\circ} 10$.

Cavadino M., Dignan, J., Penal Systems: A Comparative Approach, London 2005.

Circulaire d'orientation du 31 décembre 2010 relative à la mesure judiciaire d'investigation éducative, Bulletin Officiel du Ministère de la Justice et des Libertés, NOR : JUSF1034029C.

Cour de cassation, Chambre criminelle, du 13 décembre 1956, 55-05.772, https://www. legifrance.gouv.fr/affichJuriJudi.do?idTexte=JURITEXT000007054042 (dostęp: 25.06.2018).

Courtin Ch., France. La responsabilite penale des mineurs dans l'ordre interne et international, „Revue internationale de droit pénal” 2004, nr 1.

Dekeuwer-Défossez F., L'instrumentalisation du discernement de l'enfant, „Recherches familiales" 2012, nr 1.

Freund V., Le métier d'éducateur de la PJJ, Paris 2010.

Loi n 92-683 du 22 juillet 1992, Code pénal, Journal officiel de la République Française $\mathrm{n}^{\circ} 169$ du 23 juillet 1992.

Note d'instruction du 7 janvier 2014 relative à la mise en œuvre de l'article 12-3 de l'ordonnance du 2 février 1945 relative à l'enfance délinquante, Bulletin Officiel du Ministère de la Justice, NOR : JUSF1401444N.

Note du 23 mars 2015 relative à la mesure judiciaire d'investigation éducative, Bulletin Officiel du Ministère de la Justice et des Libertés, NOR : JUSF1507871N.

Ordonnance n ${ }^{\circ} 45-174$ du 2 février 1945 relative à l'enfance délinquante, Journal Officiel du 4 février 1945.

Stańdo-Kawecka B., Odpowiedzialność karna nieletnich a nowy kodeks karny, „Palestra” $1998, \mathrm{nr} 42$.

Stańdo-Kawecka B., Prawo karne nieletnich. Od opieki do odpowiedzialności, Warszawa 2007.

Walczak-Żochowska A., Modele postępowania z nieletnimi, [w:] Problemy prawa polskiego $i$ obcego $w$ ujęciu historycznym, praktycznym $i$ teoretycznym, cz. 4, red. B. Bieńkowska, D. Szafrański, Warszawa 2013. 


\title{
Diagnosis in criminal proceedings against juvenile offenders in France
}

\begin{abstract}
Summary
The purpose of the article is to analyse the role of diagnosis in criminal proceedings against juvenile offenders. Firstly, the conditions of juvenile criminal liability in France are presented. It is emphasised that the basic condition is being able to discern the act committed. The second part concerns the measures ordered by a judge for minors to gather information about the minor, their family situation and functioning environment. In the conclusion, the role of diagnosis in criminal proceedings is described. It is worth emphasising that the diagnosis in the French system provides support for a judge and conditions the juvenile criminal liability.
\end{abstract}

Keywords: minors, criminal liability, discernment. 